\title{
Organizacja Ogólnych Syjonistów w Polsce (1934-1939)
}

\section{Summary}

\section{Organization of General Zionists in Poland (1934-1939)}

In 1923, within the framework of the Zionist Organization in Poland (the party was active in former Russian partition and the Pomeranian and Poznań voivodeship) were formed factions, radical Al Hamiszmar and moderate Et Liwnot. The second faction postulated the emigration of Jews from Poland to Palestine based mostly on private funds. Its gathered Zionists belonging the middle and high social classes, well-educated, mostly assimilated culturally pro-Polish. Due to the deterioration of the material situation of Jews and the great economic crisis, its social influence was rapidly decreasing. In 1934, the activists factions formed new party - Organization of General Zionists in Poland. Her leader until 1939 was an attorney Leon Lewite. The party did not have much social influence. It concentrated its efforts on attempts to unite general Zionist party in Poland and in the world. It also tried to define the interests of Jews in city councils and the parliament.

Keywords: Zionism, Poland, 1918-1939

\section{Streszczenie}

W 1923 r. w ramach Organizacji Syjonistycznej w Polsce (partia działała w byłym zaborze rosyjskim oraz województwach pomorskim i poznańskim) powstały dwie frakcje: radykalna Al Hamiszmar i umiarkowana Et Liwnot. Druga frakcja postulowała emigrację Żydów z Polski do Palestyny finansowaną z funduszy prywatnych. Skupiała ona syjonistów należących do warstw średnich i wyższych, dobrze wykształconych, w znacznej części zasymilowanych kulturowo propolsko. Wobec pogarszania się położenia materialnego i wielkiego kryzysu gospodarczego jej wpływy społeczne szybko malały. W 1934 r. działacze Et Liwnot utworzyli nową partię - Organizację Ogólnych Syjonistów w Polsce. Jej przywódcą do 1939 r. był adwokat Leon Lewite. Partia nie miała większych wpływów społecznych. Koncentrowała swe wysiłki na próbach zjednoczenia partii ogólnosyjonistycznych w Polsce i na świecie. Próbowała bronić interesów Żydów w radach miejskich i sejmie.

Słowa kluczowe: syjonizm, Polska, 1918-1939 
$\mathrm{O}$ rganizacja Ogólnych Syjonistów w Polsce nie była dotychczas podmiotem opracowań. Autorzy podejmujący tematykę życia politycznego Żydów w Polsce w okresie międzywojennym nie zauważali niekiedy nawet istnienia tego ugrupowania, utożsamiając ją z Organizacją Syjonistyczną w Polsce. Warszawskie centrale syjonistyczne mające odniesienia terytorialne w nazwach „w Polsce" działały na obszarze byłego zaboru rosyjskiego (była Kongresówka i od 1925 r. na Kresach Wschodnich) oraz od 1920 r. w województwach pomorskim i poznańskim.

Podstawę źródłową do dziejów Organizacji Ogólnych Syjonistów w Polsce stanowi jej nieformalny organ prasowy, jakim był polskojęzyczny dziennik „Nasz Przegląd" (1923-1939), który powstał w momencie rozłamu Organizacji Syjonistycznej w Polsce na frakcje Al Hamiszmar i Et Liwnot. Działacze i członkowie frakcji Et Liwnot, a później Organizacji Ogólnych Syjonistów w Polsce wywodzili się ze środowiska zasymilowanych kulturowo z polskością syjonistów, należących do średnich i wyższych warstw społecznych. Pewnym uzupełnieniem gazety warszawskiej był krakowski polskojęzyczny organ Organizacji Syjonistycznej Małopolski Zachodniej, a od 1920 r. i Śląska - „Nowy Dziennik” (1918-1939). Kronikę życia politycznego Żydów prowadzono w dwumiesięczniku „Sprawy Narodowościowe” (1927-1939) wydawanym przez Instytut Badania Spraw Narodowościowych w Warszawie. Z uwagi na niepełny stan zachowania akt byłych urzędów państwowych, a także powierzchowne ich sporządzanie w odniesieniu do żydowskiego życia politycznego mają one bardzo ograniczone znaczenie dla poznania dziejów Organizacji Ogólnych Syjonistów w Polsce. Wzmianki o niej znajdujemy w zespołach: „Ministerstwo Spraw Wewnętrznych” (1919-1939) Archiwum Akt Nowych w Warszawie, „Urząd Wojewódzki Kielecki I” (1919-1939) Archiwum Państwowego w Kielcach, „Urząd Wojewódzki Lubelski-Wydział Społeczno-Polityczny" (1919-1939) Archiwum Państwowego w Lublinie, „Urząd Wojewódzki Łódzki” (1919-1939) Archiwum Państwowego w Łodzi, „Starostwo Grodzkie Krakowskie" (1919-1939) Archiwum Narodowego w Krakowie oraz „Starostwo Powiatowe Zawierciańskie” (1927-1939) (który zawiera także sprawozdania wojewody kieleckiego) Archiwum Państwowego w Katowicach.

Od początku istnienia ruch syjonistyczny na ziemiach polskich nie był jednorodny. W ramach Organizacji Syjonistycznej działającej w zaborze rosyjskim ujawniały się różne frakcje, które stopniowo ją opuszczały, tworząc samodzielne partie. Organizacja Syjonistyczna, jako partia, zajmowała w żydowskim ruchu narodowym pozycję centrową. Rozpoczęła ona legalną działalność na obszarze byłego zaboru rosyjskiego dopiero w okresie okupacji przez wojska niemieckie w 1916 r. W październiku 1917 r. odbyła się w Warszawie III konferencja syjonistyczna (później uznano ją za zjazd), w której wzięli udział przedstawicieli żydowskich organizacji narodowych z niemieckiej strefy okupacyjnej. Ujawniły się wówczas dwie frakcje w Organizacji Syjonistycznej - „starzy” i „młodzi”. Wyrazicielem poglądów pierwszej był dziennikarz Jehoszua (Heszel) Gottlieb, który za najważniejszy cel działania uważał odbudowę państw żydowskiego w Palestynie, a polityka krajowa miała być temu celowi podporządkowana. Program 
„młodych” przedstawił Maksymilian Apolinary Hartglas, kładąc nacisk na sprawy krajowe. Żydzi mieli uzyskać w przyszłości eksterytorialną autonomię narodową, a jej podstawą miała być świecka gmina. Druga frakcja opierała swój program na uchwałach III zjazdu rosyjskiej Organizacji Syjonistycznej w Helsinkach w 1906 r. ${ }^{1}$

$\mathrm{Na} V \mathrm{Z}$ jedzie Organizacji Syjonistycznej w Polsce w Łodzi na przełomie lipca i października 1921 r. ujawniły się w jej ramach dwie frakcje. „Radykalna”, kierowana przez Izaaka Grübauma, koncentrowała się na sprawach krajowych i domagała się walki opozycyjnej z rządem polskim wobec jego działań nieuwzględniających dążeń żydowskich. „Umiarkowana”, której przywódcą był lekarz, dr Jerzy Rosenblatt, postulowała dominację kwestii palestyńskich. Przewagę w partii miała wówczas druga z grup².

W pierwszej części VI Zjazdu Organizacji Syjonistycznej w Polsce obradującego w Warszawie w czerwcu 1923 r. I. Grünbaum potępił secesje i tworzenie nowych frakcji. Sprawą, która podzieliła ówczesną federację, był skład Agencji Żydowskiej - instytucji mającej współdziałać z Ligą Narodów i Wielką Brytanią w odbudowie państwa żydowskiego w Palestynie. Zwolennicy I. Grübauma uważali, że członkowie Agencji powinni być wybierani przez Światowy Kongres Żydów lub tymczasowo przez Komitet Wykonawczy Światowej Organizacji Syjonistycznej. Grupa J. Gottlieba i adwokata Leona Lewitego domagała się, aby Agencja Żydowska była reprezentacją syjonistów i niesyjonistów w równych częściach. Pragnęła ona w ten sposób pozyskać amerykańskich finansistów żydowskich, którzy nie byli związani z syjonizmem. Większość delegatów poparła J. Gottlieba i L. Lewitego. Wraz z inż. Mosesem Körnerem założyli oni Komitet Wyborczy „Merkaz” na XIII Kongres Syjonistyczny. Działania te zostaty odrzucone przez I. Grünbauma, który na znak protestu wystąpił z egzekutywy partii. Obrady zakończyły się bez przyjęcia stanowiska w sprawie składu Agencji Żydowskiej oraz wyborów prezesa Centralnego Komitetu Organizacji Syjonistycznej w Polsce ${ }^{3}$.

Spór wokół składu Agencji Żydowskiej doprowadził do ukształtowania się dwóch frakcji w łonie Organizacji Syjonistycznej w Polsce. Al Hamiszmar (Na Straży), której głównymi działaczami byli: I. Grünbaum, Mendel Ellenberg, M.A. Hartglas, Abraham Podliszewski i Ignacy Schiper, domagała się odbudowy państwa żydowskiego dzięki osadnictwu chaluców na wsiach w kibucach. Źródłami finansowania emigracji i osadnictwa miały być fundusze narodowe. Ważne miejsce w programie Al Hamiszmar zajmowała polityka krajowa - walka o rzeczywiste równouprawnienie Żydów w Polsce, w której zamierzano współpracować z Mizrachi, Hitachduthem i Poalej Syjon-Prawicą. Frakcja Et Liwnot (Czas Budować) powstała w wyniku przekształcenia Komitetu Wyborczego „Merkaz”. Dążyła ona do jak najszybszego przeprowadzenia kolonizacji

\footnotetext{
E. Mendelsohn, Zionism in Poland. The formative years 1915-1926, New Haven-London 1981, s. $43-65$.

2 W. Jaworski, Struktura i wptywy syjonistycznych organizacji politycznych w Polsce w latach 1918-1939, Warszawa 1996, s. 26-27.

3 „Nowy Dziennik” [dalej: ND], 20 VI 1923, nr 135, s. 1-2; „Nasz Przegląd” [dalej: NP], 19 VI 1923 , nr 83, s. 3; $20 \mathrm{VI}, \mathrm{nr} 84$, s. 3; $21 \mathrm{VI}$, nr 85, s. 3; $30 \mathrm{VI}$, nr 94, s. 4.
} 
wysiłkiem wszystkich Żydów, aby uzyskać przewagę liczebną nad Arabami w Palestynie. W akcji osadniczej prowadzonej na wsiach i w miastach miano wykorzystywać głównie kapitały prywatne, a także społeczne. Dlatego popierano emigrację warstw średnich i wyższych. Polityka krajowa miała być podporządkowana sprawom palestyńskim ${ }^{4}$.

Przełomowe znaczenie dla układu sił w Organizacji Syjonistycznej w Polsce miał VII zjazd partii w Warszawie w grudniu 1924 r. Większość uczestników stanowili delegaci reprezentujący Et Liwnot. Noe (Józef) Dawidsohn z Al Hamiszmar stwierdził, że zbyt ogólny statut umożliwia wstępowanie do partii osób niezwiązanych z ideologią narodową, którzy chcą dzięki niej tylko emigrować do Palestyny. Na wniosek J. Gottlieba uchwalono rezolucję o potrzebie przyciągnięcia do ruchu syjonistycznego wszystkich uznających odbudowę siedziby narodowej w Palestynie z kulturą hebrajską, co było wyrazem poparcia dla pertraktacji z kręgami amerykańskiej finansjery żydowskiej. Nowo wybrane władze partii były zdominowane przez Et Liwnot. Prezesem centralnego komitetu składającego się tylko z jej działaczy wybrano L. Lewitego, jego zastępcą J. Gottlieba 5 .

$\mathrm{Na}$ III konferencji syjonistów warszawskich w czerwcu 1926 r. doszło do próby porozumienia między obu frakcjami. Komitet miejski Organizacji Syjonistycznej w Polsce był zdominowany przez Al Hamiszmar, a władze centrali dzielnicowej przez Et Liwnot. Aby zapewnić warunki porozumienia, wybrano tymczasowe prezydium, do którego z ramienia Al Hamiszmar wszedł I. Grünbaum, z syjonistów-rewizjonistów - dr Jakub Kahan, ale Et Liwnot odmówiła desygnowania swego przedstawiciela. Grünbaum zwrócił się do Et Liwnot z propozycją podjęcia rozmów w sprawie likwidacji frakcji istniejących w Organizacji Syjonistycznej w Polsce, co zostało zaakceptowane przez L. Lewitego. Zapadła wstępna decyzja o zjednoczeniu Al Hamiszmar i Et Liwnot, co spowodowało opuszczenie obrad przez syjonistów-rewizjonistów. Ostatnia frakcja rozpoczęła działalność w Polsce w 1925 r. Postulowała ona radykalne działania wobec brytyjskich władz mandatowych w Palestynie, ponadklasowy program i rozpoczęcie kolonizacji żydowskiej w Transjordanii. Początkowo frakcja wyrażała poparcie dla Al Hamiszmar'.

Obradująca w Warszawie na przełomie października i listopada 1926 r. Rada Partyjna Organizacji Syjonistycznej w Polsce miała doprowadzić do porozumienia między frakcjami. Et Liwnot zaproponowała, aby centralny komitet składał się z 40 przedstawicieli Al Hamiszmar i 50 Et Liwnot, co zostało odrzucone. Wówczas Et Liwnot zaproponowała uchwalenie rezolucji potępiającej walki wśród syjonistów. Przeciwko temu rozwiązaniu wystąpił I. Grünbaum, oświadczając, że walka w partii ma charakter doktrynalno-programowy i będzie trwała mimo przyjęcia rezolucji. Wyłoniona komisja

Archiwum Akt Nowych w Warszawie, Ministerstwo Spraw Wewnętrznych, sygn. 1062, k. 67; NP, 8 VII 1923, nr 103, s. 6; 10 VII, nr 105, s. 2; 1 I 1925, nr 1, s. 3; E. Mendelsohn, op. cit., s. 245-250.

5 ND, 31 XII 1924, nr 291, s. 7; NP, 26 XII 1924, nr 355, s. 2; 27 XII, nr 356, s. 2; 28 XII, nr 357, s. 2; 29 XII, nr 358, s. 2.

$6 \quad$ NP, 7 VI 1926, nr 156, s. 4; 8 VI, nr 157, s. 4; 9 VI, nr 158, s. 2. 
porozumiewawcza zaproponowała, aby egzekutywa składała się w połowie z reprezentantów Al Hamiszmar i Et Liwnot, co zostało odrzucone przez drugą frakcję

Walki frakcyjne w Organizacji Syjonistycznej w Polsce były jednym z głównych tematów VIII zjazdu partii w Warszawie w lipcu 1927 r. W'śód delegatów 56\% reprezentowało Et Liwnot, 36\% - Al Hamiszmar, 6\% - syjonistów-rewizjonistów, a 2\% inne ugrupowania. W czasie obrad ukształtowało się porozumienie Al Hamiszmar i syjonistów-rewizjonistów przeciwko Et Liwnot. Dziennikarz Jakub Appenszlak z Et Liwnot oskarżył I. Grünbauma o działalność szkodliwą dla ruchu syjonistycznego w okresie jego kryzysu. Chcąc pozyskać syjonistów-rewizjonistów, wyraził poparcie dla kroków Włodzimierza Żabotyńskiego, ich przywódcy na arenie międzynarodowej na rzecz obudowy państwa żydowskiego. Przedstawiciele Al Hamiszmar koncentrowali się w swych wystąpieniach na krytyce centralnego komitetu partii. Wobec przewagi Et Liwnot wśród delegatów nowo wybrana egzekutywa składała się tylko z jej działaczy z L. Lewitem na czele. Do rady partyjnej weszło 14 przedstawicieli Et Liwnot, pięciu Al Hamiszmar i jeden syjonista-rewizjonista. Zjazd zamiast położyć kres rozbiciu partii na frakcje, spotęgował spór ${ }^{8}$.

W czasie obrad Rady Partyjnej Organizacji Syjonistycznej w Polsce w maju 1928 r. w Warszawie doszło do konfliktu między L. Lewitem a M. Körnerem, który od tej pory zaczął się zbliżać do Al Hamiszmar?. Wobec braku porozumienia między frakcjami w partii Al Hamiszmar zagroziła w styczniu 1929 r., że jeśli w najbliższym czasie nie dojdzie do zjazdu, to zwoła go przy poparciu syjonistów-rewizjonistów. Podjęto działania zmierzające do stworzenia struktury, która zmusiłaby centralny komitet do podzielenia się władzą z Al Hamiszmar. Utworzono Zjednoczenie Niezależnych Syjonistów, które uznało za podstawę porozumienia i zaprzestania walki o skład Agencji Żydowskiej, przeprowadzenie wyborów na XVI kongres syjonistyczny na podstawie demokratycznej ordynacji i zaaprobowanie polityki I. Grünbauma. Na czele nowej struktury stanęli N. Dawidsohn z Al Hamiszmar i M. Körner z Et Liwnot ${ }^{10}$.

W lutym 1929 r. Zjednoczenie Niezależnych Syjonistów wydało odezwę o jedności Organizacji Syjonistycznej w Polsce, konieczności zaprzestania walki o skład Agencji Żydowskiej i zwołania zjazdu partii. Ogłoszono, że do Zjednoczenia przystąpiły oddziały partii w: Białymstoku, Dubnie, Kaliszu, Kielcach, Kole, Kowlu, Sosnowcu, Wilnie i we Włocławku. Grünbaum oświadczył, że przyjmuje pośrednictwo Zjednoczenia w sprawie zaprzestania walki między frakcjami do czasu XVI kongresu syjonistycznego. Pertraktacje między frakcjami Organizacji Syjonistycznej w Polsce trwały

ND, 5 XI 1926, nr 246, s. 6; NP, 1 XI 1926, nr 300, s. 6; 2 XI, nr 301, s. 6; 3 XI, nr 302, s. 2; 11 XI, nr 310, s. 4 .

8 ND, 6 VII 1927, nr 175, s. 11; 9 VII, nr 178, s. 6; NP, 30 VI 1927, nr 178, s. 5; 4 VII, nr 182, s. 2; 5 VII, nr 183, s. 2; 6 VI, nr 184, s. 5; 7 VII, nr 185, s. 6; 8 VII, nr 186, s. 7; „Sprawy Narodowościowe” [dalej: $\mathrm{SN}] 1927$, nr 3, s. 297-298.

9 NP, 18 V 1928, nr 136, s. 4; 21 V, nr 139, s. 4; 7 VII, nr 186, s. 4; SN 1928, nr 2, s. 244.

10 ND, 23 I 1929, nr 23, s. 11; NP, 13 I 1929, nr 13, s. 13; 22 I, nr 22, s. 3; 25 I, nr 25, s. 7; 28 I, nr 28, s. 7; SN 1929, nr 2, s. 288-289. 
na przełomie lutego i marca 1929 r. i zakończyły się podpisaniem umowy między Al Hamiszmar i syjonistami-rewizjonistami a centralnym komitetem partii składającym się z członków Et Liwnot. Ustalono, że zjazd partii odbędzie się po kongresie syjonistycznym, a skład jej centralnego komitetu zostanie uzupełniony o przedstawicieli Al Hamiszmar i syjonistów-rewizjonistów w równych liczbach. Prezesem egzekutywy miała zostać osoba wybrana za porozumieniem wszystkich frakcji, a jej zadaniem prowadzenie spraw bieżących. Na niezależnego prezesa centralnego komitetu wybrano adwokata Borysa Stawskiego. W skład prezydium weszli z Et Liwnot - M. Hindes, L. Lewite i J. Rosenblatt, z Al Hamiszmar - I. Grünbaum i M. A. Hartlgas, a z syjonistów-rewizjonistów - J. Kahan ${ }^{11}$.

Porozumienie między frakcjami w Organizacji Syjonistycznej w Polsce było chwilowe. W czerwcu 1929 r. odbyła się w Warszawie narada Et Liwnot, na której poddano krytyce Al Hamiszmar i syjonistów-rewizjonistów. Podjęto decyzje o utworzeniu Biura Centralnego Et Liwnot pod przywództwem L. Lewitego ${ }^{12}$.

Decydujące znaczenie dla ukształtowania się sytuacji w Organizacji Syjonistycznej w Polsce miał jej IX zjazd w Warszawie w styczniu 1930 r. Wśród delegatów dominowali zwolennicy Et Liwnot, popierani wówczas przez syjonistów-rewizjonistów, a mniejszość stanowili przedstawiciele Al Hamiszmar i Zjednoczenia Niezależnych Syjonistów. Lewite określił, że celem zjazdu będzie wzmocnienie i zjednoczenie partii. Nowy centralny komitet miał składać się z reprezentantów wszystkich frakcji, a w partii miała zwyciężyć tolerancja i miało dojść do uspokojenia nastrojów. Przedstawiciele Et Liwnot krytykowali wystąpienia działaczy Al Hamiszmar i syjonistów-rewizjonistów. Syjoniści-rewizjoniści uznali, że nie ma różnic programowych między Al Hamiszmar a Et Liwnot i należy utworzyć wspólne kierownictwo partii. Rosenblatt wezwał do likwidacji frakcji. Körner skrytykował L. Lewitego. Józef Rawicki z Al Hamiszmar zaproponował wybór centralnego komitetu przez wszystkich delegatów, a nie jak chciała Et Liwnot - dokonać podziału miejsc między frakcje. Syjoniści-rewizjoniści zapowiedzieli, że wejdą do egzekutywy, o ile nastąpi wspótpraca między Al Hamiszmar a Et Liwnot. Grünbaum podjął działania mające doprowadzić do rozbicia Et Liwnot i pozyskania części jej działaczy. Stwierdził, że M. Hindes, L. Lewite i J. Rosenblatt pragną porozumienia z Al Hamiszmar, a część Et Liwnot z J. Gottliebem go nie chce. Jednak trzej przywódcy Et Liwnot odmówili współpracy z I. Günbaumem, pragnęli bowiem utworzenia koalicyjnego centralnego komitetu w wyniku podziału miejsc. Nie mogąc pozyskać Al Hamiszmar, doprowadzili do wstrzymania się od głosowania delegatów frakcji i syjonistów-rewizjonistów w wyborach. Prezesem egzekutywy w miejsce zmarłego w grudniu 1929 r. B. Stawskiego, składającej się tylko z przedstawicieli Al Hamiszmar, wybrano I. Grünbauma. W skład rady partyjnej miało

11 ND, 13 II 1929, nr 43, s. 6; 7 III, nr 65, s. 6; 12 III, nr 70, s. 7; NP, 3 II 1929, nr 34, s. 6; 5 III, nr 64, s. 4; 7 III, nr 66, s. 7; 7 IV, nr 97, s. 6; SN 1929, nr 2, s. 289-290.

12 NP, 10 VI 1929, nr 158, s. 2; 11 VI, nr 159, s. 9. 
wejść: dziewięciu członków Al Hamiszmar, dziewięciu Et Liwnot, pięciu syjonistów-rewizjonistów i dwóch syjonistów niezależnych ${ }^{13}$.

W listopadzie 1930 r. odbyło się w Warszawie posiedzenie Rady Partyjnej Organizacji Syjonistycznej w Polsce, opanowanej przez Al Hamiszmar, ponieważ działacze Et Liwnot nie weszli do niej po IX zjeździe partii. Opowiedziano się za utrzymaniem linii politycznej I. Grünbuama. W kwietniu 1931 r. obradował w Warszawie zjazd krajowy Et Liwnot. W czasie dyskusji nad działalnością Komitetu Wykonawczego Światowej Organizacji Syjonistycznej wobec kwestii palestyńskiej ujawniły się dwie grupy: J. Gottlieb, S. Heftman i L. Lewite domagali się jego ustąpienia, a J. Appenszlak i J. Rosenblatt uznali, że uczynił on wszystko, co było możliwe. Zjazd podjął rezolucje o niewstępowaniu działaczy frakcji do Rady Partyjnej Organizacji Syjonistycznej w Polsce do czasu następnego zjazdu. Do Biura Centralnego Et Liwnot weszli: J. Appenszlak, lekarz - dr Zygmunt Bychowski, J. Gottlieb, S. Heftman, L. Lewite i J. Rosenblatt ${ }^{14}$.

Najbardziej reprezentatywnym miernikiem wpływów frakcji Et Liwnot w ramach żydowskiego ruchu narodowego były wyniki wyborów na kongresy syjonistyczne na obszarze dzielnicy warszawskiej. Pierwszy raz frakcja wzięła samodzielny udział w wyborach na XIV Kongres Syjonistyczny w Wiedniu w 1925 r. Na podstawie fragmentarycznych danych można przypuszczać, że oddano na nią wówczas około 53\% głosów uzyskanych przez Organizację Syjonistyczną w Polsce ${ }^{15}$. W wyborach na XV Kongres Syjonistyczny w Bazylei (wyniki bez Wileńszczyzny) w 1927 r. Et Liwnot zdobyła 6069 głosów (20,3\% wszystkich), Al Hamiszmar - 3018 (12,8\%), syjoniści-rewizjoniści 1352 (4,5\%) ${ }^{16}$; na XVI w Zürichu w 1929 r. Et Liwnot - 7092 (14,5\%), Al Hamiszmar - 7337 (15,0\%), syjoniści-rewizjoniści - $4229(8,7 \%)^{17}$; na XVII w Bazylei w 1931 r. Et Liwnot - 3915 (5,5\%), Al Hamiszmar - 10220 (14,3\%), syjoniści-rewizjoniści - $20144(28,1 \%)^{18}$; a na XVIII w Pradze w 1933 r. Et Liwnot - 2803 (1,3\%), Al Hamiszmar - 25440 (12,2\%), Organizacja Syjonistów-Rewizjonistów (partia powstała w 1933 r.) - $48158(23,0 \%)^{19}$.

Wybuch wielkiego kryzysu ekonomicznego spowodował radykalizację nastrojów wśród ludności żydowskiej w Polsce, w tym syjonistów. Stale pogarszało się położenie materialne ludności żydowskiej, co powodowało, że wizja odbudowy państwa żydowskiego z wykorzystaniem prywatnych środków stała się nierealna. Wobec spadku wpływów społecznych kierownictwo Et Liwnot zdało sobie sprawę z niemożliwości

13 ND, 2 I 1930, nr 2, s. 8; 9 I, nr 8, s. 2; NP, 6 I 1930, nr 6, s. 5-6; 7 I, nr 7, s. 5; 8 I, nr 8, s. 4; SN 1932, nr 6, s. 693.

14 Archiwum Państwowe w Łodzi [dalej: APŁ], Urząd Wojewódzki Łódzki [dalej: UWŁ], sygn. 2507/h, k. 43; NP, 14 IV 1931, nr 101, s. 9; 15 IV, nr 102, s. 6.

15 NP, 3 VIII 1925, nr 212, s. 1; 4 VIII, nr 213, s. 3; 5 VIII, nr 214, s. 6.

16 NP, 9 VIII 1927, nr 218, s. 4.

17 NP, 7 VII 1929, nr 184, s. 4; 10 VI 1931, nr 158, s. 2.

18 NP, 12 VI 1931, nr 160, s. 1.

19 NP, 6 VIII 1933, nr 219, s. 4; 8 VIII, nr 221, s. 4; SN 1933, nr 4, s. 413. 
zdominowania Organizacji Syjonistycznej w Polsce. Przywódcy frakcji utworzyli w styczniu 1932 r. nową strukturę - Centralne Biuro Ogólnych Syjonistów i zapowiedzieli, że nie weźmie ona udziału w X Zjeździe Organizacji Syjonistycznej w Polsce.

W czasie obrad kongresu syjonistycznego w 1931 r. ukształtowały się dwa nurty partii ogólnosyjonistycznych. Do Grupy A (Światowy Związek Syjonistów Radykalnych) przystąpiła frakcja Al Hamiszmar, a do Grupy B (Światowy Związek Ogólnych Syjonistów) - Et Liwnot.

Na przełomie stycznia i lutego 1932 r. obradował w Warszawie X Zjazd Organizacji Syjonistycznej w Polsce, na który przybyli reprezentanci Al Hamiszmar, Zjednoczenia Niezależnych Syjonistów oraz mniejszości Et Liwnot, głównie z województwa łódzkiego. Grübaum uznał, że mimo nieobecności syjonistów-rewizjonistów i większości Et Liwnot, zjazd reprezentuje centrum ruchu syjonistycznego. Przedstawiciele Et Liwnot, M. Braude i J. Rosenblatt obwinili I. Grünbauma za upadek syjonizmu w Polsce. Do wybranego centralnego komitetu weszli obok Al Hamiszmar działacze Zjednoczenia Niezależnych Syjonistów oraz mniejszości: M. Braude i J. Rosenblatt. Zjazd ogłosił likwidację biorących w nim udział frakcji. Wkrótce J. Rosenblatt oświadczył o rozwiązaniu Et Liwnot bez porozumienia z Biurem Centralnym Ogólnych Syjonistów ${ }^{20}$.

Mimo ogłoszenia likwidacji Et Liwnot przez J. Rosenblatta frakcja w dalszym ciągu działała. W listopadzie 1933 r. odbyła się w Warszawie jej konferencja. Ówczesnymi przywódcami fakcji byli: Z. Bychowski, J. Gottlieb, S. Heftman i L. Lewite. Na VI konferencji syjonistów warszawskich w styczniu 1934 r. J. Gottlieb zaatakował Centralny Komitet Organizacji Syjonistycznej w Polsce za przyłączenie się do walki lewicy syjonistycznej z pozostałymi partiami ruchu narodowego. Wyraził jednak gotowość do kompromisu i chęć opracowania warunków współpracy ze wszystkimi stronnictwami syjonistycznymi ${ }^{21}$.

W Warszawie w sierpniu 1934 r. obradował XI Zjazd Organizacji Syjonistycznej w Polsce. Wśród delegatów większość stanowili działacze Al Hamiszmar, a resztę głównie Et Liwnot. Rosenblatt wskazał, że zadaniem zjazdu powinno być doprowadzenie do porozumienia między frakcjami. W czasie obrad ukształtowała się nowa grupa Jedność Syjonistyczna „Achwa”, której przewodził działacz Et Liwnot M. Hindes. Stwierdził on, że w Al Hamiszmar doszło do rozłamu na część pragnącą porozumienia z Et Liwnot oraz jemu przeciwną. Wezwał do rozwiązania komitetów ogólnosyjonistycznych tworzonych przez Et Liwnot na prowincji i rozpoczęcia rozmów zjednoczeniowych. Appenszlak opowiedział się za ogólnym, ponadklasowym syjonizmem, ale bez syjonistów-socjalistów. W czasie obrad doszło do zbliżenia między Al Hamiszmar a Et Liwnot. Porozumienie miało dotyczyć metod kolonizacji w Palestynie. Al Hamiszmar popierała osadnictwo chaluców przy wsparciu funduszy narodowych, a Et Liwnot -

\footnotetext{
NP, 6 I 1932, nr 6, s. 4; 15 I, nr 15, s. 9; 1 II, nr 32, s. 2; 2 II, nr 33, s. 3; 3 II, nr 34, s. 3; 4 II, nr 35, s. 8.

21 ND, 15 XI 1933, nr 313, s. 9; NP, 3 I 1934, nr 3, s. 6.
} 
członków warstw średnich i wyższych z prywatnych środków finansowych. Do porozumienia jednak nie doszło i zjazd opuścili delegaci Et Liwnot ${ }^{22}$.

Przełomową rolę w konsolidacji ruchu syjonistycznego w Polsce miała odegrać narada działaczy reprezentujących centrale dzielnicowe w Krakowie 11 listopada 1934 r. Przedstawiciele Organizacji Syjonistycznej w Polsce (zdominowanej przez Al Hamiszmar) omawiali z władzami Światowego Związku Ogólnych Syjonistów, do którego należała Et Liwnot, sprawę przystąpienia do niego. Formalnym powodem braku porozumienia była kwestia dyscypliny w wyborach Komitetu Wykonawczego Światowej Organizacji Syjonistycznej. W głosowaniu nad problemami programowymi i wyborem egzekutywy delegaci centrali warszawskiej postulowali podejmować decyzje kwalifikowaną większością głosów (2/3), a jeśli nie udałoby się jej uzyskać, wówczas mniejszość miałaby swobodę głosowania nad tymi sprawami na kongresach syjonistycznych. Natomiast Światowy Związek Ogólnych Syjonistów godził się na tę propozycję, ale tylko w odniesieniu do spraw programowych. Frakcja Et Liwnot ogłosiła samo rozwiązanie, a jej członkowie mieli wstąpić bezpośrednio do Światowego Związku ${ }^{23}$.

Prawdopodobnie 16 grudnia 1934 r. członkowie byłej frakcji Et Liwnot utworzyli na zebraniu (które uznano później za I zjazd partii) w Warszawie nową partię - Organizację Ogólnych Syjonistów w Polsce. Na jej czele stanął L. Lewite. Doprowadziło to do działania w dzielnicy warszawskiej dwóch partii ogólnosyjonistycznych. Organizacja Syjonistyczna w Polsce była kontynuacją frakcji Al Hamiszmar i grup, które oderwały się od Et Liwnot. Wkrótce oświadczyła ona, że do nowej partii należy tylko część członków byłej Et Liwnot, a większość jest w dalszym ciągu jej członkami. Między obu stronnictwami rozpoczęła się rywalizacja o podporządkowanie sobie oddziałów terenowych. Egzekutywa Organizacji Syjonistycznej w Polsce dążyła do zmajoryzowania nowej partii. Demonstracyjnie pozostawiła w składzie swej egzekutywy miejsca dla przedstawicieli byłej Et Liwnot ${ }^{24}$.

W odpowiedzi Tymczasowy Komitet Wykonawczy Organizacji Ogólnych Syjonistów w Polsce oświadczył, że jest jedynym stronnictwem w byłym zaborze rosyjskim wiernym programowi ogólnosyjonistycznemu i oskarżył Organizację Syjonistyczną w Polsce o uniemożliwienie zjednoczenia ogólnych syjonistów oraz zażądał przystąpienia jej do Światowego Związku. Stwierdził, że egzekutywa Organizacji Syjonistycznej w Polsce skupia tylko radykałów - członków Al Hamiszmar, którzy przeciwstawiają się zjednoczeniu partii ogólnosyjonistycznych na obszarze całej II Rzeczypospolitej. Natomiast Tymczasowy Komitet Wykonawczy Organizacji Ogólnych Syjonistów stawiał sobie za cel unifikację z Organizacjami Syjonistycznymi Małopolski Wschodniej oraz Małopolski Zachodniej i Śląska. Egzekutywa Światowej Organizacji Syjonistycznej

22 ND, 1 IX 1934, nr 242, s. 14; NP, 26 VIII 1934, nr 243, s. 5; 27 VIII, nr 244, s. 2; 28 VIII, nr 245, s. 9; 29 VIII, nr 246, s. 9; 30 VIII, nr 247, s. 9; 12 IX, nr 259, s. 4.

23 ND, 12 XI 1934, nr 310, s. 11; 13 XI, nr 311, s. 1; 19 XII, nr 347, s. 14; NP, 13 XI 1934, nr 320, s. 4; $14 \mathrm{XI}, \mathrm{nr} 321$, s. 10; $19 \mathrm{XI}$, nr 326, s. 9.

24 NP, 19 XII 1934, nr 356, s. 14. 
w Londynie, zdominowana przez radykałów i lewicę, potępiła powstanie nowej partii, prowadziło to bowiem do rozbicia ruchu syjonistycznego. W każdym kraju mogła istnieć tylko jedna partia ogólnosyjonistyczna i dlatego nakazano członkom Organizacji Ogólnych Syjonistów w Polsce powrót do Organizacji Syjonistycznej w Polsce ${ }^{25}$. Sytuacja na ziemiach polskich była ewenementem, gdyż państwo było początkowo podzielone na cztery dzielnice syjonistyczne, a od 1925 r. na trzy, co było następstwem zaborów.

W Wilnie, w którym wśród ogólnych syjonistów dominowały wpływy Al Hamiszmar, na czele syjonistycznego komitetu miejskiego stali Jakub Wygodzki (niezwiązany z żadną frakcją) oraz dwaj jego zastępcy: Izrael Michał Lubiński-Styczyński (Al Hamiszmar) i inż. Eliasz Spiro (Et Liwnot). W listopadzie 1934 r. doszło do rozłamu w komitecie. Syjoniści należący do Et Liwnot na początku grudnia 1934 r. utworzyli oddział Światowego Związku Ogólnych Syjonistów i zerwali z Centralnym Komitetem Organizacji Syjonistycznej w Polsce. Władze oddziału tworzyli J. Wygodzki, E. Spiro i Jakub Szerskin ${ }^{26}$.

Działalność dwóch partii ogólnosyjonistycznych w byłym zaborze rosyjskim spowodowała interwencję Komitetu Wykonawczego Światowej Organizacji Syjonistycznej. Jej przywódca Berl Loker wydał w lutym 1935 r. oświadczenie, że Et Liwnot może wyrażać własne poglądy i rekrutować nowych członków Organizacji Syjonistycznej, a gdy zdobędzie większość, będzie mogła legalną drogą dążyć do przyjęcia jej programu, ale nie wolno jej tworzyć drugiej centrali dzielnicowej oraz nawoływać do występowania z Organizacji Syjonistycznej w Polsce ${ }^{27}$.

Wydaje się, że utworzenie Organizacji Ogólnych Syjonistów w Polsce było rezultatem głównie frustracji członków Et Liwnot, której wpływy wraz z pogarszaniem się położenia materialnego ludności żydowskiej w Polsce stale malały. Frakcja skupiała głównie przedstawicieli warstw średnich i wyższych. Pierwszym sprawdzianem wpływów nowej partii były wybory na XIX Kongres Syjonistyczny w Lucernie, przeprowadzone w dzielnicy warszawskiej 28 lipca i 4 sierpnia 1935 r. Nie są znane wyniki z 4 sierpnia. Na listę Organizacji Ogólnych Syjonistów w Polsce oddano 4458 głosów, co stanowiło 2,6\% wszystkich ${ }^{28}$. W Warszawie partia zdobyła 500 głosów (3,8\% wszystkich), w Radomiu - 164 (10,6\%), w Częstochowie - 137 (4,3\%), w Kielcach - 84 (3,1\%), w Łodzi - 42 (0,6\%), a w Lublinie - $32(1,7 \%)^{29}$.

W porównaniu z wynikami wyborów na kongresy z lat 1931 i 1933 nastąpił wzrost liczby uzyskanych głosów. Można to wiązać z efektem powstania nowego bytu

\footnotetext{
NP, 19 XII 1934, nr 356, s. 10; 22 XII, nr 359, s. 9.

NP, 31 XII 1934, nr 268, s. 5.

NP, 12 II 1935, nr 43, s. 7; 13 II, nr 44, s. 10.

ND, 3 VIII 1935, nr 211, s. 14; SN 1937, nr 4-5, s. 464.

29 Archiwum Państwowe w Katowicach, Starostwo Powiatowe Zawierciańskie, sygn. 55, k. 164; Archiwum Państwowe w Lublinie, Urząd Wojewódzki Lubelski - Wydział Społeczno-Polityczny, sygn. 178, k. 7; APE, UWŁ, sygn. 2507/l, k. 123; ND, 30 VII 1935, nr 207, s. 12; 31 VII, nr 208, s. 14.
} 
politycznego w ruchu syjonistycznym, co zawsze budzi zainteresowanie i nadzieje wyborców. Jednak nie osiągnięto liczby głosów oddawanych na Et Liwnot w połowie lat dwudziestych.

Ważną rolę dla Organizacji Ogólnych Syjonistów w Polsce miała odegrać IV Konferencja Światowa Ogólnych Syjonistów, która odbyła się w Krakowie w czerwcu 1935 r. Jej celem było doprowadzenie do skupienia wszystkich partii ogólnosyjonistycznych w ramach Światowego Związku Ogólnych Syjonistów. Jej fiasko skłoniło nową partię we wrześniu 1935 r. do podjęcia działań zmierzających do unifikacji trzech centrali krajowych w Polsce należących do Światowego Związku Ogólnych Syjonistów. Prezes partii L. Lewite został upoważniony do pertraktacji z Organizacją Syjonistyczną Małopolski Wschodniej oraz Organizacją Syjonistyczną Małopolski Zachodniej i Śląska. Dnia 26 stycznia 1936 r. odbyła się we Lwowie narada przedstawicieli tych partii, na której postanowiono utworzyć Ogólno Syjonistyczną Radę Naczelną w Polsce. Wezwano Organizację Syjonistyczną w Polsce do współpracy ${ }^{30}$.

Nowe ordynacje wyborcze do Sejmu i Senatu w 1935 r. były początkowo niezrozumiane przez kierownictwa żydowskich partii narodowych w Polsce, w tym Organizacji Ogólnych Syjonistów. Sądziły one, że istniała możliwość wpływania na proces wyłaniania kandydatów. Na przełomie czerwca i lipca 1935 r. za udziałem w wyborach opowiedziała się m.in. nowa partia ogólnosyjonistyczna. Rozpoczęły się negocjacje dotyczące współpracy w wyborach na obszarze byłego zaboru rosyjskiego z Mizrachi, Agudas Izrael i Centralą Związku Kupców. Doprowadziły one do powstania 20 lipca „Zjednoczonego Żydowskiego Bloku Wyborczego”. Jednak wobec sporów 26 lipca doszło do upadku porozumienia, do którego chciała przystąpić Organizacja Syjonistów-Rewizjonistów. Dnia 12 sierpnia Organizacja Ogólnych Syjonistów w Polsce, mimo istniejących ograniczeń, postanowiła wziąć udział w wyborach i domagała się utworzenia bloku ogólnożydowskiego ${ }^{31}$.

Dnia 10 sierpnia 1935 r. zgromadzenia wyborcze w Warszawie ustaliły listy kandydatów w wyborach do Sejmu Rzeczypospolitej Polskiej, wśród których znalazł się J. Gottlieb. Wkrótce, 20 sierpnia Organizacja Ogólnych Syjonistów w Polsce wraz z Mizrachi, Organizacją Syjonistów-Rewizjonistów i Stronnictwem Państwa Żydowskiego (partia powstała po rozłamie w ruchu syjonistów-rewizjonistów w 1933 r., początkowo pod nazwą Związek Syjonistów-Demokratów) utworzyły w Warszawie „Żydowski Blok Wyborczy”, który miał popierać kandydaturę J. Gottlieba. W wyniku wyborów w stolicy z 8 września do sejmu z okręgu nr 2 wszedł żydowski kandydat Bezpartyjnego Bloku Współpracy z Rządem Wacław Wiślicki, a nie J. Gottlieb. Organizacja Ogólnych Syjonistów w Polsce podejrzewała wyborcze nadużycia. Dnia 20 stycznia 1936 r.

30 Archiwum Narodowe w Krakowie, Starostwo Grodzkie Krakowskie, sygn. 134, k. 137-138; ND, 17 VI 1935, nr 165, s. 1-3; 18 VI, nr 166, s. 12; 19 VI, nr 167, s. 12; 23 IX, nr 262, s. 7; 29 I 1936, nr 29, s. 13; NP, 17 VI 1935, nr 172, s. 4; 18 VI, nr 173, s. 4; 19 VI, nr 174, s. 4 i 9; 1 VII, nr 186, s. 5.

31 ND, 21 VIII 1935, nr 198, s. 11; NP, 3 VII 1935, nr 188, s. 4; 18 VII, nr 203, s. 2 i 10; 19 VII, nr 204, s. 4; 21 VII, nr 206, s. 8; 23 VII, nr 208, s. 8; 2 VIII, nr 218, s. 10; 13 VIII, nr 229, s. 2. 
sprawa znalazła się w Sadzie Najwyższym. Ponieważ W. Wiślicki zmarł 3 października 1935 r., 4 maja 1936 r. sąd przyznał po nim mandat J. Gottliebowi, bez rozpatrywania skargi wyborczej ${ }^{32}$.

Prawdopodobnie 13 grudnia 1935 r. na posiedzeniu Centralnego Komitetu Organizacji Ogólnych Syjonistów w Polsce mówiono o konieczności utworzenia wspólnego frontu syjonistycznego w celu obrony zagrożonych praw ludności żydowskiej. Partia miała nawiązać współpracę z pozostałymi ugrupowaniami narodowymi, aby stworzyć polityczną reprezentację Żydów w Polsce. Dnia 5 kwietnia 1936 r. odbyła się w Warszawie narada przedstawicieli Organizacji Ogólnych Syjonistów w Polsce, Organizacji Syjonistycznej w Polsce, Organizacji Syjonistycznej Małopolski Wschodniej, Organizacji Syjonistycznej Małopolski Zachodniej i Śląska, Mizrachi, Stronnictwa Państwa Żydowskiego oraz Syjonistycznej Partii Pracy Hitachduth. Front miał się zajmować prowadzeniem polityki krajowej, a także pomocą prawną i społeczną Żydom ${ }^{33}$.

W dniach 14-15 czerwca 1936 r. obradował w Warszawie II Zjazd Organizacji Ogólnych Syjonistów w Polsce, na który przybyło 436 delegatów z 217 miejscowości. Wzięli w nim udział przedstawiciele: parlamentarnego Koła Żydowskiego, Światowego Związku Ogólnych Syjonistów, Organizacji Syjonistycznej Małopolski Wschodniej oraz Organizacji Syjonistycznej Małopolski Zachodniej i Śląska. Prezes L. Lewite oskarżył Komitet Wykonawczy Światowej Organizacji Syjonistycznej o nieuzasadniony optymizm w sprawie powstania państwa żydowskiego w Palestynie oraz niezjednoczenie ruchu syjonistycznego wbrew zapowiedziom XIX kongresu syjonistycznego. Sam ruch narodowy został osłabiony, ponieważ jego kierownictwo znalazło się w rękach lewicy. Ruch syjonistyczny miał mieć charakter ponadklasowy i ponadpartyjny. Postulował unifikację ogólnych syjonistów. Appenszlak domagał się rozwoju rolnictwa żydowskiego oraz stworzenia żydowskiej formacji zbrojnej w Palestynie. Gottlieb stwierdził, że ogólnym syjonistom przypadła walka z partyjniactwem w ruchu narodowym i doprowadzenie do jego zjednoczenia. Podkreślał, że mimo starań nie udało się dotychczas utworzyć ogólnopolskiej reprezentacji Żydów. Uważał, że niezależnie od warunków, należy zawsze brać udział w wyborach parlamentarnych. Wskazywał na wzrost antysemityzmu oraz pogarszanie się położenia materialnego ludności żydowskiej w Polsce. Thon zwrócił uwagę na trudności gospodarcze Palestyny, co miało być winą brytyjskich władz mandatowych. Zaproponował utworzenie w niej żydowskich instytucji kredytowych. Goszczący przywódca Światowego Związku Ogólnych Syjonistów, dr Ignacy Schwartzbart powiedział, że ogólni syjoniści zostali zepchnięci na peryferie ruchu narodowego przez lewicę, a muszą być silną, zwartą partią. W Palestynie miał panować solidaryzm narodowy, a nie walka klasowa. Dostrzegał on możliwości rozwoju syjonizmu ogólnego w byłej Kongresówce. Uznał, że nie należy bezpodstawnie

32 ND, 10 IX 1935, nr 249, s. 1-2; 13 IX, nr 252, s. 13; 23 IX, nr 262, s. 7; 5 V 1936, nr 123, s. 1; NP, 15 VIII 1935, nr 231, s. 2; 21 VIII, nr 237, s. 4; 1 IX, nr 248, s. 5; 10 IX, nr 257, s. 2; 13 IX, nr 260, s. 4; 21 I 1936, nr 21, s. 2; 5 V, nr 134, s. 4.

33 ND, 15 XII 1935, nr 343, s. 3; 9 IV 1936, nr 99, s. 14; SN 1936, nr 3, s. 285. 
krytykować egzekutywy światowej. Emil Schmorak z Organizacji Syjonistycznej Małopolski Wschodniej podkreślił, że syjonizm jest ideą narodową, a nie klasową. Senator Mojżesz Schorr wezwał do zjednoczenia ogólnych syjonistów. Zjazd wyraził poparcie dla ogólnosyjonistycznej organizacji robotniczej w Palestynie - Irgun Haowdim Hacijonim, domagał się zjednoczenia organizacji ogólnosyjonistycznych w Polsce i współpracy w ramach Komitetu Politycznego z Mizrachi, Organizacją Syjonistów-Rewizjonistów i Stronnictwem Państwa Żydowskiego. Przyjęto m.in. uchwały o: konieczności dymisji Wysokiego Komisarza Arthura Grenfella Wauchopego za niezapewnienie Żydom bezpieczeństwa w Palestynie, żądaniu wypełnienia przez Brytyjczyków deklaracji Jamesa Arthura Balfoura, powołaniu żydowskiej formacji wojskowej w Palestynie, utworzeniu Rady Gospodarczej dla Palestyny przez światową egzekutywę, założeniu banków dla rolnictwa, przemysłu i handlu oraz hipotecznego w Palestynie, rozwoju osadnictwa młodzieży ogólnosyjonistycznej w Palestynie, propagandzie na rzecz funduszy narodowych, poparciu dla działań Koła Żydowskiego w polskim parlamencie, rozwoju ogólnego syjonizmu wśród młodzieży i rzemieślników. Prezesem egzekutywy wybrano L. Lewitego, a w jej skład weszli również Henryk Rosmarin i Emil Sommerstein z Organizacji Syjonistycznej Małopolski Wschodniej, co miało symbolizować dążenia unifikacyjne ${ }^{34}$.

Nikłe wpływy społeczne skłoniły Organizację Ogólnych Syjonistów do współpracy $\mathrm{z}$ innymi partiami narodowymi w wyborach do rad zarządów małych gmin żydowskich 30 sierpnia 1936 r. oraz rad wielkich gmin 6 września. Wraz z Organizacją Syjonistyczną w Polsce, Stronnictwem Państwa Żydowskiego i organizacjami gospodarczymi utworzyła ona „Zjednoczony Blok Narodowy”35.

Narastający antysemityzm w II Rzeczypospolitej skłaniał Organizację Ogólnych Syjonistów w Polsce także do współpracy z pozostałymi żydowskimi partiami narodowymi w celu obrony praw i interesów Żydów. W połowie listopada 1936 r. powstała komisja ją koordynująca, składająca się z przedstawicieli: Organizacji Syjonistycznej w Polsce, Organizacji Ogólnych Syjonistów w Polsce, Organizacji Syjonistycznej Małopolski Wschodniej oraz Organizacji Syjonistycznej Małopolski Zachodniej i Śląska. W następnym miesiącu omawiano plan działania tej komisji, który miał polegać na utworzeniu ciała reprezentującego Żydów wobec władz państwowych w Polsce i instytucji międzynarodowych ${ }^{36}$.

W czerwcu 1937 r. z inicjatywy parlamentarzystów żydowskich utworzono, mającą bronić interesów ludności wyznania mojżeszowego, Tymczasową Reprezentację Żydostwa Polskiego, do której weszli przedstawiciele: Organizacji Ogólnych Syjonistów w Polsce, Organizacji Syjonistycznej Małopolski Wschodniej, Organizacji Syjonistycznej Małopolski Zachodniej i Śląska, Organizacji Syjonistów-Rewizjonistów,

34 ND, 15 VI 1936, nr 164, s. 3; 16 VI, nr 165, s. 12; NP, 15 VI 1936, nr 176, s. 4; 16 VI, nr 177, s. 11 ; 24 VI, nr 185, s. 9; SN 1936, nr 3, s. 285.

35 NP, 2 VIII 1936, nr 225, s. 19; 3 VIII, nr 226, s. 13; 6 VIII, nr 229, s. 13.

36 SN 1936, nr 4-5, s. 655. 
Stronnictwa Państwa Żydowskiego, Tora Weawoda (organizacja młodzieżowa związana z Mizrachi) oraz Agudas Izrael i Poalej Agudat Izrael. Nie przystąpiły do Reprezentacji: Organizacja Syjonistyczna w Polsce, Hitachduth, Poalej Syjon-Prawica oraz Żydowskie Stronnictwo Demokratyczno-Ludowe (folkiści), prowadzące akcję na rzecz konkurencyjnego Kongresu Żydostwa Polskiego, który miał być jednolitą strukturą broniącą interesów ludności żydowskiej. Do prac miano przyciągnąć pozostałe partie żydowskie, w tym głównie Mizrachi. Działania te potwierdzały głębokie rozbicie ruchu syjonistycznego w Polsce na dwa obozy: umiarkowany, zdominowany przez ogólnych syjonistów, oraz radykalny ${ }^{37}$.

Pośrednim efektem konsolidacji partii narodowych było powstanie w grudniu 1937 r. Zjednoczonego Komitetu Syjonistycznego, który obejmował ugrupowania z byłego zaboru rosyjskiego: Mizrachi, Stronnictwo Państwa Żydowskiego, Organizacje Syjonistyczną w Polsce, Organizacje Ogólnych Syjonistów w Polsce, Hitachtuth, Poalej Syjon-Prawicę i organizację młodzieżową Hanoar Hacioni, któremu przewodziła Organizacja Syjonistyczna w Polsce ${ }^{38}$.

Kompromisowa postawa Organizacji Ogólnych Syjonistów w Polsce wobec swego głównego konkurenta politycznego - Organizacji Syjonistycznej w Polsce wynikała ze stałego spadku wpływów społecznych. Wielki kryzys gospodarczy i panująca po nim depresja pogarszała położenie materialne Żydów w Polsce, w tym warstw średnich i w części wyższych, do których partia adresowała swój program.

Dnia 11 lipca 1937 r. odbyły się w dzielnicy warszawskiej wybory na XX Kongres Syjonistyczny w Zürichu. Organizacja Ogólnych Syjonistów w Polsce otrzymała 3049 głosów (co stanowiło 2,8\% wszystkich). W Warszawie oddano na partię 248 głosów (3,0\%), w Radomiu - 205 (13,4\%), w Częstochowie - 200 (6,4\%), a w Łodzi 129 $(2,0 \%)^{39}$. W porównaniu z $1935 \mathrm{r}$. nastąpił spadek liczby głosów uzyskanych przez partię ogółem o ponad $31 \%$, ale odsetek zdobytych głosów wzrósł o ponad $8 \%$. Zmniejszyła się bowiem liczba osób biorących udział w wyborach na kongres syjonistyczny. Wynikało to z narastającej apatii politycznej ludności żydowskiej uwarunkowanej sytuacją wewnętrzną Polski oraz sytuacją międzynarodową.

Prawdopodobnie 22 lipca 1937 r. odbyło się posiedzenie Centralnego Komitetu Organizacji Ogólnych Syjonistów w Polsce. Thon przedstawił na nim problematykę zbliżającego się kongresu syjonistycznego. Został on wybrany delegatem partii na niego. Omawiano także sytuację ekonomiczną panującą w Palestynie. W kilka dni później członkowie naczelnych władz partii dyskutowali o nieprawidłowościach w czasie wyborów na kongres syjonistyczny ${ }^{40}$. W dniu 25 października na posiedzeniu egzekutywy podjęto decyzję o zwołaniu posiedzenia Rady Partyjnej Organizacji Ogólnych Syjonistów w Polsce na połowę listopada. Do centralnego komitetu przyjęto S. Sziffa

SN 1937, nr 3, s. 304-305; nr 4-5, s. 457.

Ibidem, nr 6, s. 663-664.

Archiwum Państwowe w Kielcach, Urząd Wojewódzki Kielecki I, sygn. 2597 II, k. 167; NP, 12 VIII

1937, nr 201, s. 4; 13 VII, nr 202, s. 13; 20 VII, nr 209, s. 12; SN 1937, nr 4-5, s. 463-464.

40 NP, 23 VII 1937, nr 212, s. 11; 26 VII, nr 215, s. 10. 
z Palestyny. Zdecydowano o pomocy finansowej dla Palestyny z powodu panującego tam kryzysu gospodarczego. Dnia 11 listopada 1937 r. obradowała rada partyjna. Dyskusja koncentrowała się wokół sytuacji w światowym ruchu syjonistycznym i położenia Żydów w Polsce. Referaty wygłosili prezes L. Lewite oraz. J. Appenszlak, B. Ołomucki i J. Thon. W obradach uczestniczył przywódca Światowego Związku Ogólnych Syjonistów I. Schwartzbart ${ }^{41}$.

Słabła działalność organizacyjna naczelnych władz Organizacji Ogólnych Syjonistów w Polsce. Na posiedzeniu egzekutywy w Warszawie 8 maja 1938 r. omawiano sytuację w światowym ruchu syjonistycznym i partii. Referat sprawozdawczy wygłosił J. Thon. Rozpoczęto przygotowania do zjazdu partii, który planowano na czerwiec tego roku. Jednak do konferencji krajowej nie doszło. Na posiedzeniu centralnego komitetu 2 lipca mówiono o połączeniu ogólnych syjonistów w Polsce oraz Światowego Związku Ogólnych Syjonistów i Światowego Zjednoczenia Ogólnych Syjonistów (powstały w 1935 r. następca Światowego Związku Syjonistów Radykalnych). Od marca 1938 r. Organizacja Ogólnych Syjonistów w Polsce prowadziła negocjacje o unifikacjach w ramach powołanej przez Komitet Wykonawczy Światowej Organizacji Syjonistycznej „komisji sześciu”. Składała się ona z trzech przedstawicieli Organizacji Syjonistycznej w Polsce oraz po jednym Organizacji Ogólnych Syjonistów w Polsce, Organizacji Syjonistycznej Małopolski Wschodniej oraz Organizacji Syjonistycznej Małopolski Zachodniej i Śląska. Przewodniczyli jej L. Lewite oraz M. Kleinbaum z Organizacji Syjonistycznej w Polsce. Do tematu powrócono na następnym posiedzeniu w dniach 22-23 lipca. Dyskutowano wtedy również o problemach emigracji żydowskiej do Palestyny ${ }^{42}$.

Mimo obowiązywania ograniczającej demokrację ordynacji w wyborach samorządowych Centralny Komitet Organizacji Ogólnych Syjonistów w Polsce 9 sierpnia 1938 r. zdecydował o udziale w nich w ramach ,jednolitego frontu narodowego”. Partia 29 września wraz z Agudas Izrael, Mizrachi i stowarzyszeniami zawodowo-gospodarczymi utworzyła „Ogólnożydowski Blok Narodowy do Rady Miejskiej Warszawy”, do którego przystąpiły później Organizacja Syjonistów-Rewizjonistów i Stronnictwo Państwa Żydowskiego. Organizacja Ogólnych Syjonistów nie zdobyła w tych wyborach żadnego mandatu ${ }^{43}$.

W dniach 20-22 września 1938 r., w związku ze zbliżającymi się wyborami do sejmu i senatu, odbyły się narady przedstawicieli egzekutyw: Organizacji Syjonistycznej w Polsce, Organizacji Ogólnych Syjonistów w Polsce, Organizacji Syjonistycznej Małopolski Wschodniej oraz Organizacji Małopolski Zachodniej i Śląska. Mimo obowiązywania antydemokratycznych ordynacji Organizacja Ogólnych Syjonistów w Polsce postanowiła wziąć w nich udział w ramach „ogólnożydowskiego bloku wyborczego”.

NP, 26 X 1937, nr 305, s. 11; 3 XI, nr 313, s. 12; 11 XI, nr 321, s. 12.

42 NP, 9 V 1938, nr 130, s. 14; 3 VII, nr 184, s. 11; 24 VII, nr 206, s. 25; SN 1938, nr 1-2, s. 128; nr 3, s. 311-312.

43 NP, 11 VIII 1938, nr 225, s. 12; 12 VIII, nr 226, s. 12; 30 X, nr 304, s. 4; 12 XII, nr 347, s. 4, 15; 20 XII, nr 355, s. 4 . 
Popierany przez partię adwokat Salomon Seidenman został zatwierdzony 13 października przez kolegium elektorskie na kandydata do sejmu w okręgu nr 2 w Warszawie. Od tego momentu jego kandydaturę wspierał Żydowski Narodowy Komitet Wyborczy. W dniu 6 listopada 1938 r. S. Seidenmana wybrano na posła ${ }^{44}$.

Egzekutywa partii 28 września 1938 r. powróciła do kwestii zwołania III Zjazdu Organizacji Ogólnych Syjonistów w Polsce. Początkowo planowano przeprowadzić go w grudniu, a w październiku przesunięto termin jego obrad na początek stycznia 1939 r. Centralny komitet partii, obradujący 22 grudnia 1938 r., uchwalił jednak, że konferencja krajowa odbędzie się 25-26 lutego następnego roku ${ }^{45}$.

Organizacja Ogólnych Syjonistów w Polsce próbowała rozszerzyć swe wpływy społeczne. Na posiedzenie prezydium centralnego komitetu 29-30 stycznia 1939 r. zaproszono działaczy organizacji młodzieżowych Akiba, Hanoar Hacioni i HAZ (Histadrut Akademim Zionim), aby zacieśnić współpracę. Potępiono działalność Organizacji Syjonistycznej w Polsce ${ }^{46}$.

$\mathrm{Na}$ tle udziału w rozliczeniach finansowych Agencji Żydowskiej między Polską a Palestyną dotyczących emigracji Żydów doszło na początku 1939 r. do rozdźwięków między Organizacją Ogólnych Syjonistów a Organizacją Syjonistyczną Małopolski Wschodniej oraz Organizacją Syjonistyczną Małopolski Zachodniej i Śląska. Schwartzbart wystąpił przeciwko udziałowi Organizacji Ogólnych Syjonistów w pracach komitetu kolonizacyjnego. Słabnąca pozycja Organizacji Ogólnych Syjonistów w Polsce i konflikty w łonie jej kierownictwa skłoniły J. Gottlieba do ustąpienia z egzekutywy na jej posiedzeniu 14 lutego 1939 r. Na tym posiedzeniu uchwalono rezolucję o mobilizacji Żydów na rzecz Palestyny, poparciu dla działającej w niej organizacji robotniczej Irgun, a także zwiększeniu ofiar na rzecz funduszy narodowych ${ }^{47}$.

Narastające trudności wewnętrzne i apatia członków Organizacji Ogólnych Syjonistów Polsce spowodowały, że planowany III zjazd krajowy nie doszedł do skutku. Obradująca 28 lutego 1939 r. jej egzekutywa pod przywództwem L. Lewitego zapowiedziała zwołanie rady partyjnej na 19 marca, a zjazd przesunęła na nieokreśloną przyszłość. W posiedzeniu centralnego komitetu wzięli udział E. Schmorak i I. Schwartzbart ${ }^{48}$.

Zgodnie z zapowiedzią 19 marca 1939 r. obradowała Rada Partyjna Organizacji Ogólnych Syjonistów w Polsce. Lewite potępił zdominowany przez lewicę Komitet Wykonawczy Światowej Organizacji Syjonistycznej i jego udział w konferencji londyńskiej na przełomie lutego i marca w sprawie Palestyny. Thon wygłosił referat

\footnotetext{
44 NP, 20 IX 1938, nr 265, s. 11; 22 IX, nr 267, s. 11; 24 IX, nr 269, s. 11; 14X, nr 288, s. 12; 5 XI, nr 310, s. 5; 7 XI, nr 312, s. 2; 6 XI, nr 313, s. 2.

NP, 30 I 1939, nr 30, s. 14

NP, 17 II 1939, nr 48, s. 7; SN 1939, nr 1-2, s. 143.

8 NP, 1 III 1939, nr 60, s. 12; 9 III, nr 68, s. 12; 18 III, nr 77, s. 12.
} 
o ogólnym syjonizmie, Seidenmann o polityce krajowej, a Schiff z Palestyny o znaczeniu nowego funduszu Keren Haowed Hacioni. Wyrażono poparcie dla Żydowskiego Koła Parlamentarnego ${ }^{49}$.

Na posiedzeniu Centralnego Komitetu Organizacji Ogólnych Syjonistów w Polsce obradującym 8 maja 1939 r. ponownie podniesiono sprawę zwołania zjazdu partii. Zapowiedziano go na czerwiec. Na następnym posiedzeniu egzekutywy 1 i 5 czerwca już nie powrócono do kwestii konferencji krajowej. W posiedzeniu centralnego komitetu wziął udział prezes Światowego Związku Ogólnych Syjonistów I. Schwartzbart. Żądano od Agencji Żydowskiej powołania do życia Komitetu Ocalenia Narodowego wobec już bezpośredniego zagrożenia ludności żydowskiej w Polsce i Europie Środkowej przez hitleryzm. Potępiono rząd brytyjski za wydanie „białej księgi”, w której uzależniano powstanie państwa żydowskiego w Palestynie od woli miejscowych Arabów. Na posiedzeniu Rady Partyjnej Organizacji Ogólnych Syjonistów 10 czerwca ponownie domagano się stworzenia Komitetu Ocalenia Narodowego ${ }^{50}$.

Dnia 3 lipca 1939 r. Organizacja Ogólnych Syjonistów przy wsparciu Akiby, Hanora Hacioni i HAZ rozpoczęła kampanię wyborczą na zbliżający się kongres. W jej czasie pojawiła się myśl porozumienia w sprawie podziału mandatów delegatów i rezygnacji z wyborów. Prezes partii L. Lewite krytykował działania zdominowanej przez lewicę Agencji Żydowskiej oraz rządu brytyjskiego ograniczającego imigrację Żydów do Palestyny, a także domagał się zaprzestania „walki klas” w ramach narodu żydowskiego i zastąpienie jej solidaryzmem. Wybory na XXI Kongres Syjonistyczny w Genewie w dzielnicy warszawskiej odbyły się 23 i 30 lipca 1939 r. Na listę Organizacji Ogólnych Syjonistów w Polsce oddano 2924 głosy, co stanowiło 2,2\% wszystkich. W Warszawie partia zdobyła 258 głosów (3,5\%), a w Łodzi 166 (1,9\%). Ponad 50 głosów na jej listę padło w Będzinie, Częstochowie, Lublinie, Łomży, Poznaniu i Radomiu. W porównaniu w wyborami z 1937 r. nastąpił spadek liczby bezwzględnej i większy względnej uzyskanych głosów ${ }^{51}$. Było to następstwo stałego wzrostu wpływów lewicy syjonistycznej.

Wyniki wyborów na kongres syjonistyczny były tematem obrad Rady Partyjnej Organizacji Ogólnych Syjonistów w Polsce 6 sierpnia 1939 r. Przewodniczył im przywódca partii L. Lewite. Delegatem na kongres wybrano J. Thona ${ }^{52}$.

Podziały społeczne, a w części i kulturowe działaczy Organizacji Syjonistycznej w Polsce doprowadziły do ukształtowania się w jej ramach w 1923 r. dwóch frakcji: radykalnej Al Hamiszmar i umiarkowanej Et Liwnot. Druga z nich domagała się skoncentrowania na odbudowie państwa żydowskiego w Palestynie głównie dzięki funduszom prywatnym. Wśród emigrujących Żydów z Polski mieli początkowo dominować

\footnotetext{
49 NP, 20 III 1939, nr 79, s. 14; 27 III, nr 86, s. 14.

$50 \mathrm{NP}, 10 \mathrm{~V} 1939$, nr 130, s. 14; $8 \mathrm{VI}$, nr 159, s. 11; $11 \mathrm{VI}$, nr 162, s. 10.

51 NP, 5 VII 1939, nr 186, s. 11; 13 VII, nr 194, s. 12; 22 VII, nr 203, s. 6; 24 VII, nr 205, s. 1; 25 VII, nr 206, s. 12-13; 26 VII, nr 207; 6 VIII, nr 218, s. 25.

52 NP, 8 VIII 1939, nr 220, s. 12.
} 
członkowie warstw średnich i wyższych. Polityka krajowa miała być podporządkowana kwestiom palestyńskim. W połowie lat dwudziestych przewaga należała do Et Liwnot. Jednak pogarszanie się położenia materialnego ludności żydowskiej i wybuch wielkiego kryzysu gospodarczego zminimalizowały jej wpływy społeczne. Przyczyną tego było adresowanie przez frakcję swego programu do wąskich, zamożniejszych i dobrze wykształconych warstw społecznych, które uległy w znacznym stopniu propolskiej asymilacji kulturowej. Narastający konflikt z Al Hamiszmar i frustracja przywódców Et Liwnot doprowadziły w 1934 r. do przekształcenia jej w samodzielną partię - Organizację Ogólnych Syjonistów w Polsce. Przywódcą partii do 1939 r. był adwokat Leon Lewite. Wbrew nadziejom nowa partia, w porównaniu z Et Liwnot, nie zwiększyła znacząco wpływów społecznych w drugiej połowie lat trzydziestych. Koncentrowała one swe wysiłki głównie na próbach zjednoczenia partii ogólnosyjonistycznych w II Rzeczypospolitej i w ramach Światowej Organizacji Syjonistycznej. Dążyła także do obrony interesów ludności żydowskiej w radach miejskich i sejmie.

\section{Bibliografia (Bibliography)}

\section{Źródła archiwalne}

Archiwum Akt Nowych w Warszawie

Ministerstwo Spraw Wewnętrznych, sygn. 1062.

Archiwum Narodowe w Krakowie

Starostwo Grodzkie Krakowskie, sygn. 134.

Archiwum Państwowe w Katowicach

Starostwo Powiatowe Zawierciańskie, sygn. 55.

Archiwum Państwowe w Kielcach

Urząd Wojewódzki Kielecki I, sygn. 2597 II.

Archiwum Państwowe w Lublinie

Urząd Wojewódzki Lubelski-Wydział Społeczno-Polityczny, sygn. 178.

Archiwum Państwowe w Łodzi [APŁ]

Urząd Wojewódzki Łódzki [UWŁ], sygn. 2507/h, 2507/l.

\section{Prasa}

„Nasz Przegląd” 1923-1939.

„Nowy Dziennik” 1923-1924, 1926-1927, 1929-1930, 1933-1936.

„Sprawy Narodowościowe” 1927-1929, 1932-1933, 1936-1939. 


\section{Opracowania}

Jaworski W., Struktura i wptywy syjonistycznych organizacji politycznych $w$ Polsce $w$ latach 1918-1939, Warszawa 1996.

Mendelsohn E., Zionism in Poland. The formative years 1915-1926, New Haven-London 1981.

\section{Notka o autorze:}

\section{dr Wojciech Jaworski (1960-)}

Zainteresowania badawcze: dzieje życia społeczno-politycznego na ziemiach polskich w latach 1864-1970, w tym szczególnie ruchu syjonistycznego oraz ludności żydowskiej na Górnym Śląsku i w Zagłębiu Dąbrowskim.

그wjaworski7@gmail.com 